University of Nebraska - Lincoln

DigitalCommons@University of Nebraska - Lincoln

Journal for the Advancement of Developing

Economies

Economics Department

2012

The US Financial Crisis, Emerging Markets and the Effects of IMF

Loans

Bridgette Bain

University of New Orleans

Follow this and additional works at: https://digitalcommons.unl.edu/jade

Part of the Econometrics Commons, Growth and Development Commons, International Economics Commons, Political Economy Commons, Public Economics Commons, and the Regional Economics Commons

Bain, Bridgette, "The US Financial Crisis, Emerging Markets and the Effects of IMF Loans" (2012). Journal for the Advancement of Developing Economies. 16.

https://digitalcommons.unl.edu/jade/16

This Article is brought to you for free and open access by the Economics Department at DigitalCommons@University of Nebraska - Lincoln. It has been accepted for inclusion in Journal for the Advancement of Developing Economies by an authorized administrator of DigitalCommons@University of Nebraska - Lincoln. 


\title{
The US Financial Crisis, Emerging Markets and the Effects of IMF Loans
}

\author{
Bridgette Bain \\ University of New Orleans
}

\begin{abstract}
The main hypothesis of this paper is that emerging markets with outstanding debt from the IMF and their economies are more severely affected by shocks to the world than countries that do not undertake IMF debt. The effect that shocks have on these economies is also dependent upon the size of the debt borrowed. This paper analyzes the effects that outstanding IMF debt has on emerging markets. Essentially, it observes the responses of emerging markets to shocks in their economy when they are indebted to the IMF. We observe 35 emerging markets as defined by Dow Jones in 2010 and find that the GDP of the countries indebted to the IMF were more adversely affected by the US Financial Crisis than their counterparts who never indulged in IMF credit as well as those countries that were able to fully repay their debt. Our analysis indicated that not only being indebted to the IMF affected their ability to recover from the crisis but examines how the size of the debt played an integral role in their economy's stability. Ultimately, we conclude that the IMF may be at fault in enabling emerging markets to collapse from accumulation of debt from which they are unable to repay.
\end{abstract}

Keywords: IMF Debt, Emerging Markets, US Financial Crisis, Economic Stability

\section{INTRODUCTION}

According to the University of Iowa Center for International Finance and Development, emerging markets are countries that have strategically positioned themselves to experience rapid growth and industrialization $(\mathrm{Li}, 2012)$. These countries not only experience rapid growth spurts but award lucrative returns to risk loving investors in areas of trade, technology transfers, and foreign direct investments. Ashoka Mody (2004) in "What is an emerging market?" also describes it as the place where a country is positioned such that it is searching for an acute tradeoff between commitment and flexibility in contractual agreements. As noted by the World Bank, the five largest emerging markets on the globe are China, India, Indonesia, Brazil, and Russia (Li, 2012).

Evidently, emerging markets often suffer detrimentally from shocks that hit their economies. Often times, these shocks are not terribly severe and developed nations almost always fully recover from them. Unfortunately, one of the main characteristics of an emerging market that lends itself to the mercy of these shocks is the volatility of these underdeveloped nations. Since many developing countries are not fully stable, they are unable to withstand normal or, much less so, severe abnormalities that may hit their economies. 
According to the Business Wire News database, February 2009, the US Financial Crisis of 2008, also known as the Global Financial Crisis, has been the worst financial crisis experienced by the US since the Great Depression in the 1930's (Pendery, 2009). The crisis, triggered by a lack of liquidity in the US markets, led to a housing bubble, the necessary bailout of multi-billion dollar corporations, and a devastated investor confidence in the global stock market.

Unfortunately, but not completely unbeknown to the public, the United States Senate issued a report to confirm that the crisis was not a natural disaster, but the spiraling effect of too many risky investments, deliberate inaccuracy of credit ratings, and little to no monitoring.

Consequently, this financial crisis could have been prevented with an earlier intervention. Nonetheless, this paper will aim to examine the effects that the crisis had on emerging markets, segmented into categories of countries that have outstanding IMF debt, have repaid all their IMF debt, and those who never took an IMF loan.

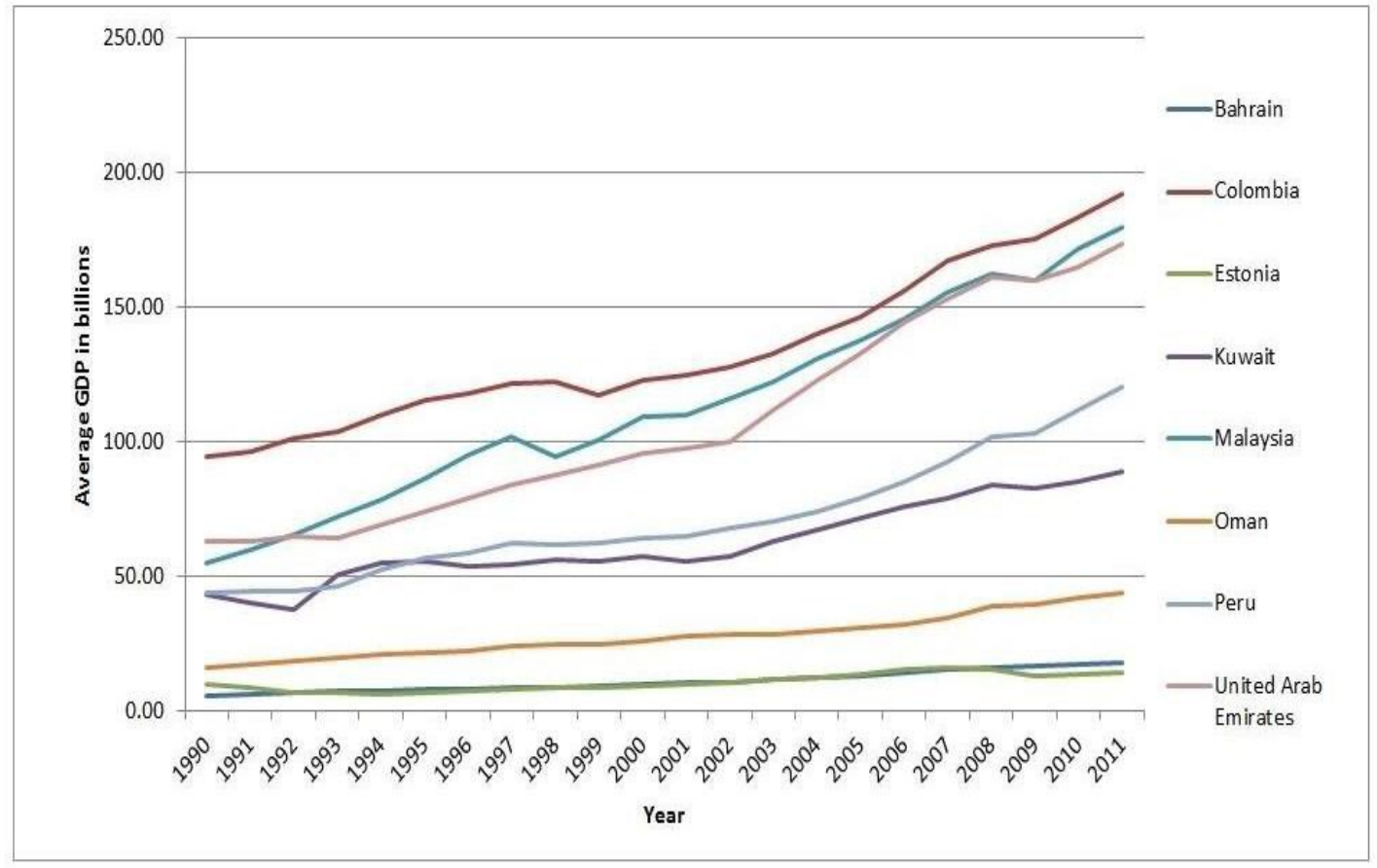

Figure 1. GDP of Countries with Emerging Markets That Have Never Been Indebted to the Fund, 1990-2011

Figure 1 illustrates the GDP of a sample of emerging markets that never received IMF credit within the period 1990-2011.This data was collected from the World Bank World Development Indicators, International Financial Statistics of the IMF, IHS Global Insight, and Oxford Economic forecasting, as well as estimated and projected values developed by the Economic Research Service all converted to a 2005 base year. (When this data was gathered, because of the use of fixed exchange rates, for consistent and accurate interpretation, the exchange rates of the 2005 USD was utilized in calculating the listed GDPs). 
We can observe nx from this figure that during the 2007-2009 financial crisis, there was not an extensive dip in GDP of countries who never undertook IMF credit, and most of these economies were able to recover and grow after the end of the crisis.

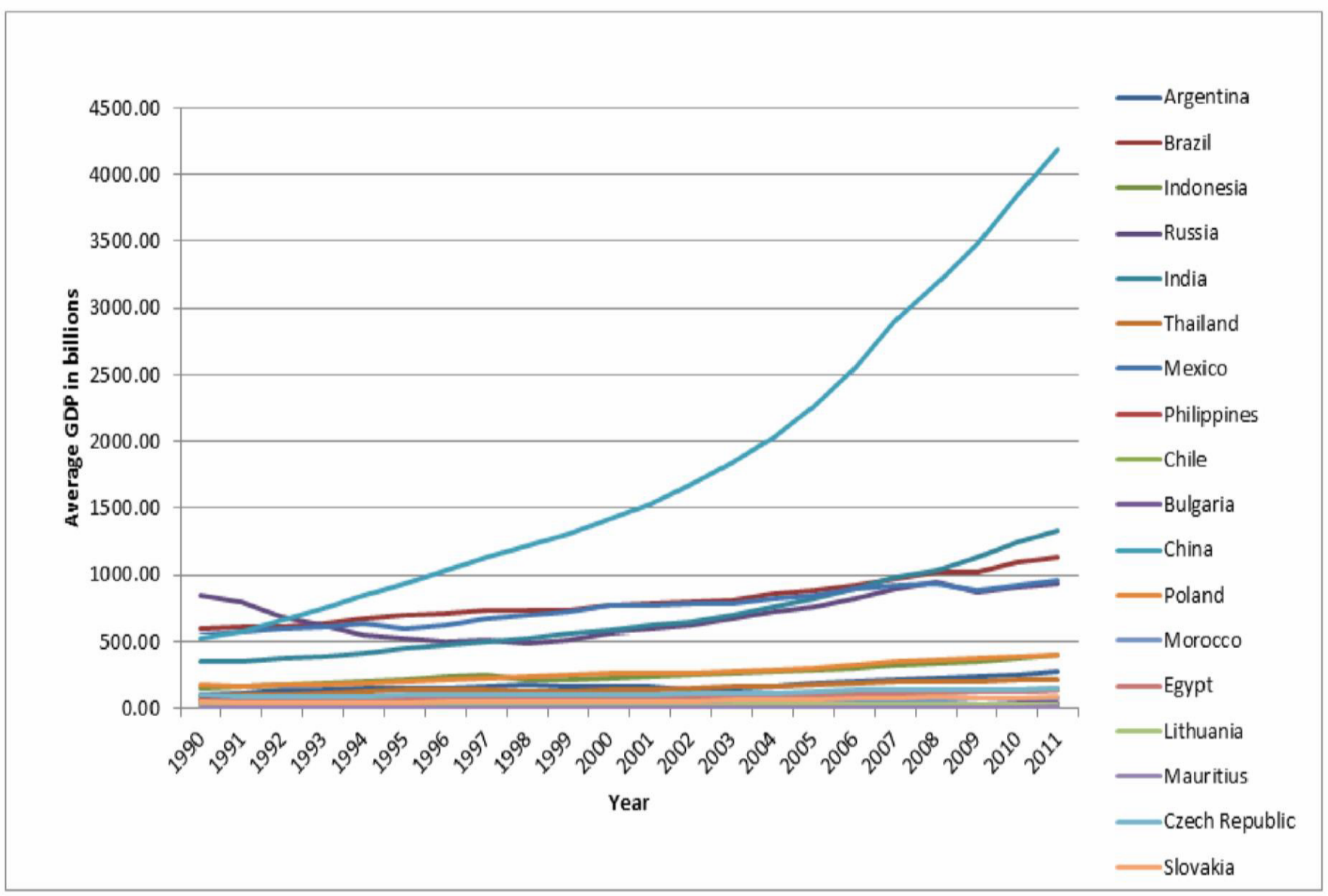

Figure 2. GDP of Countries with Emerging Markets that Have Fully Repaid Their Debt, 19902011

Figure 2 illustrates the GDP of countries who received IMF credit but had fully repaid the debt within the 1990-2011 period. From our diagram, we can also observe that most of these countries were able to weather the 2007-2009 financial crisis and flourish afterward.

Figure 3 highlights the GDP of countries in the period 1990-2011 that are currently indebted to the IMF. In this figure, it is easier to observe the drop-in country GDP during the 2007-2009 period. This drop that is conspicuous in Romania, Hungary and Latvia are not quite as common in countries that never undertook IMF debt or undertook debt but fully repaid it. 


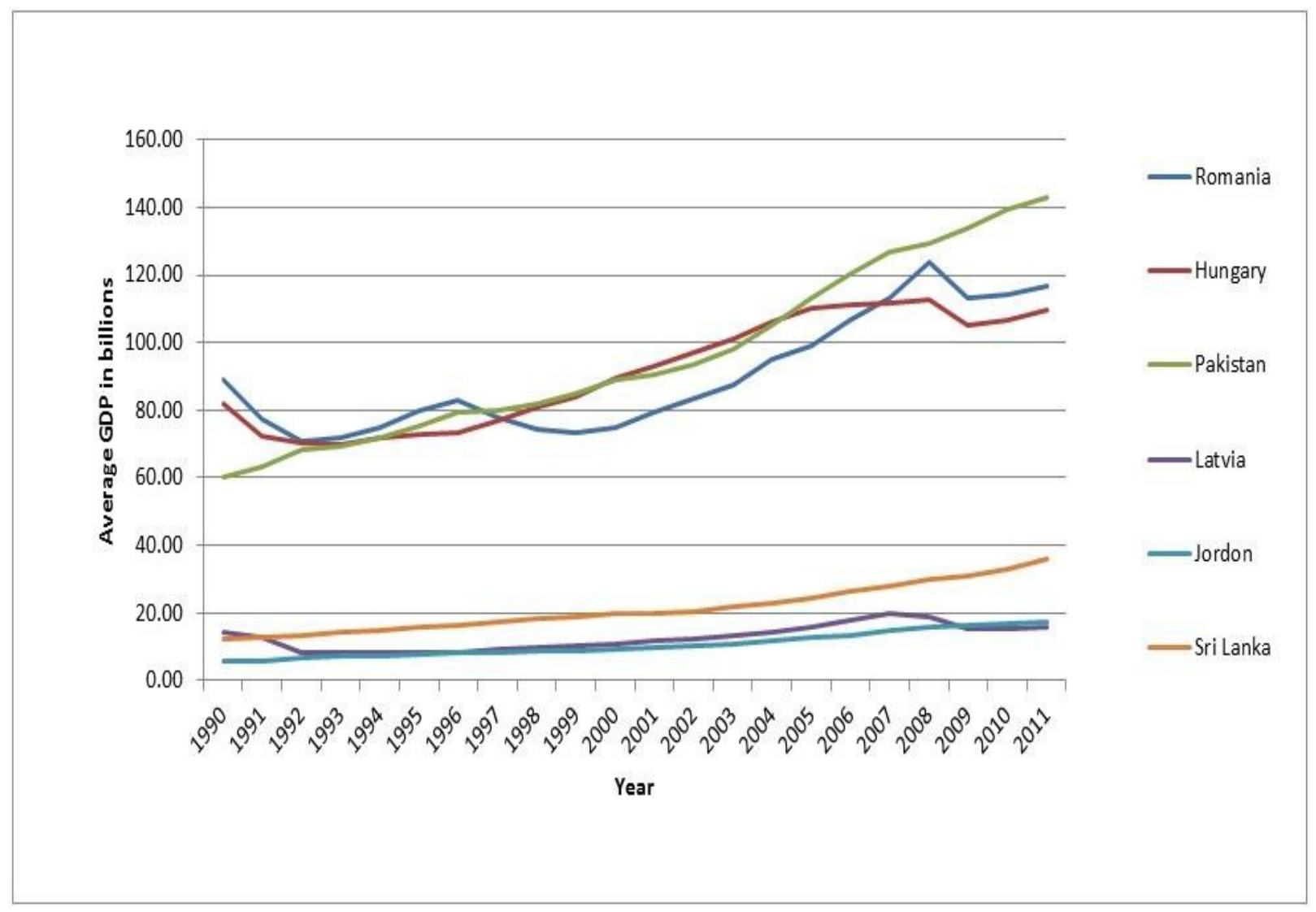

Figure 3. GDP of Countries with Emerging Markets Which Are Currently Indebted to the Fund, 1990-2011

\section{LITERATURE REVIEW}

The International Monetary Fund (IMF) is an organization reconstructed in 1944 with a defined mission: to foster global monetary cooperation, secure financial stability, facilitate international trade, promote high employment levels, sustain economic growth, and reduce poverty around the globe. Feldstein (1998) notes that the IMF was originally formed to help countries cope with trade deficits and temporary shortages of foreign exchange but has a new emphasis on structural and institutional reform, an avenue that has not always been a part of the IMF's agenda.

As noted in Bird (1996), the demand for IMF credits is positively correlated with balance-ofpayments deficits and negatively correlated with availability of alternative means of financing. Evidently, balance-of payments deficits are a direct spillover of domestic fiscal and monetary mismanagement, increased import prices, and overvalued exchange rates. Ultimately, Bird concludes that since the IMF is a source of last resort, lending it can be expected to be inversely related to the level of economic development in an emerging market. In addition, studies conducted around IMF lending suggests that the probability that a country will request IMF credit, in the short run, is positively related to its previous involvement with the Fund (Bird, 1996). 
He also notes that many countries tend to resist borrowing from the IMF even if they are in dire need because of the perceived political cost attached. In addition, while the Fund had high stipulations and conditions attached to borrowing, researchers have found that the Fund relaxed its conditions and requirements necessary to receive credit immediately after the 1982 debt crisis. Consequently, it became easier at this time for countries to engage in IMF borrowing; this action taken by the IMF increased the likelihood of countries being unable to repay their debts as well as the hold that the Fund had on their economy.

He determined that since a loan from the IMF is laid out as temporary and revolving, receivership of the loan should be looked at as a failure on a country's path. In addition, if the Fund's program does not encourage economic improvement for countries who took credit but instead engender the same countries to engage in requesting additional credits without showing signs of paralleling improvement, the Fund fails at its pre-assigned purpose.

Bird (1996) finds that though countries exhibit the criteria necessary to meet conditions to receive the Fund's credit, the goal of improving the country's macroeconomic conditions is often left unrealized. While some argue that the Fund does a poor job on following up on the countries that undertake their debt to ensure that they comply with the conditions with which the money was lent, there is also speculation, arguing, that these countries may have set their goals unrealistically high (Bird, 1996).

Joyce (1992) finds that countries more likely to enter Fund arrangements are countries which tend to have excessively high ratios of government expenditure to GDP and low ratios of international reserves to imports. These countries evidently exhibit signs of distress, contributing to the theory of failure on their part. Logit regressions conducted by Joyce (1992) on 29 countries during the period 1972-1984 illustrate that the most significant determinants of a country's likelihood to apply for IMF credit are inflation, export growth, the ratio of foreign exchange reserves to imports, the ratio of external debt to GNP, the ratio of net foreign direct investment to GNP, and the rate of nominal exchange rate depreciation. In addition, it was found by Edwards and Santaella (1993) that participation in an IMF program is a determinant in a country's likelihood to devalue its currency as well.

Oftentimes the IMF has been accused of strategically positioning itself to have a semi-permanent presence in many needy, developing countries. The programs that they initiate and fund sometimes enable countries in their downward spiral, causing them to be dependent on their (the IMF's) funding for a long haul.

In the 1980s, the only users of the Fund were developing nations. The need for IMF funding exponentially increased during the oil shocks of the 1970s and the rapid growth of commercial bank in the 1980s which led to the debt crisis. Initially the Fund worked as a credit union, pooling the funds of various countries allowing each to draw from it as necessary. After the crises of the 80s and the oil shock of the 70s, the role of the IMF began to shift. The IMF began to act as a financial intermediary, borrowing resources from one group of countries and lending to another group. As the Fund's role began to change they started to take on a more political agenda encouraging its members to utilize their credit. Finally, the Fund is now being criticized for being part of the problem by taking resources from debtor countries instead of creating wealth. 


\section{METHODOLOGY}

The purpose of this paper is to determine whether a relationship exists between an emerging market having IMF credit and the ability to withstand shocks, specifically the US Financial Crisis. The contribution I intend to make with this paper is to decipher whether it is unbeneficial in the long run for countries to accept IMF credit, particularly for countries that are more likely to default on their IMF loans. The first step will be to group the emerging markets into three categories: countries that currently owe the IMF, countries that once had IMF credit but fully repaid it all, and countries that never engaged in credit dealings with the IMF.

The emerging markets that I will consider are countries defined as emerging markets by Dow Jones in 2010. This list includes Argentina, Bahrain, Brazil, Bulgaria, Chile, China, Columbia, Czech Republic, Egypt, Estonia, Hungary, India, Indonesia, Jordan, Kuwait, Latvia, Lithuania, Malaysia, Mauritius, Mexico, Morocco, Oman, Pakistan, Peru, Philippines, Poland,

Qatar, Romania, Russia, Slovakia, South Africa, Sri Lanka, Thailand, Turkey and United Arab Emirates. Though there are many more emerging markets across the globe, the countries selected have more easily attainable historical data available (citation here). The goal is to observe whether taking on IMF credit has an effect on the GDP of an emerging market.

First, we gather data on our 35 emerging markets regarding loans solicited from the IMF. This data is publicly available on the IMF's official website. We then divide our sample into 3 groups, the number indicating the IMF credit status:

1. Countries that never accepted credit from the IMF (-1)

2. Countries that have accepted credit but currently have a zero balance and ( 0$)$

3. Countries that have accepted credit and are still in the repayment period. (1)

The next step would be to gather data on the GDP growth rates of the 35 emerging markets from 1980 to 2009. The GDP growth rates, according to Bartelsman and Beaulieu (2004) in 'A Consistent Accounting of US Productivity Growth', are the sum of income received by all sectors of an economy in a country. It includes all wages, taxes, and profits less subsidies. The number should reflect the market value of all final goods and services made within the borders of the country in a specific year. Consequently, this is a good indicator of measuring the temperature of an economy, particularly in and around a crisis. For this reason, we consider GDP as the sole explanatory variable in determining a country's ability to survive a financial crisis.

From this step we would find the descriptive statistics of the GDP growth rates from 1980 to 2009 of each emerging market. If any country has less than 10 years of growth rate data it would be omitted from the data set. This would avoid any unexplainable variances in the means. More specifically, if any event occurred in a particular region at a specific time period, we want all the growth rates to be reflective of the event. Needless to say, if some growth rates are missing, it would create a bias in the data.

Table 1 reports the descriptive statistics of the GDP growth rates. These include the mean, standard deviation, variance, minimum and maximum of each country. We can observe that Kuwait, Latvia, 
Slovakia and Lithuania have the highest standard deviation of growth rates from 1981-2010. In contrast, rapidly growing economies like China, Oman and India have the highest mean growth rates. This is indicative of the steadily increasing growth rates of more stable economies in spite of shocks experienced, as expected.

Table 2 represents the descriptive statistics on the emerging markets' GDP in billions. Similar to Table 1, we want to observe and analyze the mean, variance, maximum and minimum of the GDP of the emerging markets represented in our data set. It is noteworthy to observe that China, Russia, Brazil and Mexico also have among the highest average GDP. These emerging markets are the fastest growing in the world.

Table 3 notes the total amount drawn by the emerging markets over the period 1980-2009 as well as the IMF credit status of each emerging market. This data is divided up into 3 variables as previously defined. -1 for "never received credit from the IMF during our time period 1980 to 2009", 0 for "received credit from IMF but currently has no outstanding debt" and 1 for "received credit from IMF and still carries a balance on the account."

Table 1: Descriptive Statistics of countries' annual GDP growth rates (in percentages) over the period 1981-2010

\begin{tabular}{|c|c|c|c|c|c|}
\hline Country & Mean & Std Dev & Variance & Minimum & Maximum \\
\hline China & 10.09 & 2.83 & 8.01 & 3.80 & 15.20 \\
\hline Oman & 6.29 & 5.08 & 25.79 & -3.44 & 17.05 \\
\hline India & 6.27 & 2.26 & 5.13 & 1.06 & 9.82 \\
\hline Malaysia & 5.96 & 4.04 & 16.29 & -7.36 & 10.00 \\
\hline Thailand & 5.63 & 4.55 & 20.71 & -10.51 & 13.29 \\
\hline Indonesia & 5.35 & 4.07 & 16.55 & -13.13 & 9.08 \\
\hline Mauritius & 5.06 & 2.18 & 4.74 & 0.38 & 9.74 \\
\hline Pakistan & 4.97 & 1.99 & 3.96 & 1.01 & 7.92 \\
\hline Egypt & 4.97 & 1.87 & 3.51 & 1.08 & 9.91 \\
\hline Sri Lanka & 4.87 & 1.91 & 3.67 & -1.55 & 8.01 \\
\hline Chile & 4.72 & 4.42 & 19.54 & -10.32 & 12.28 \\
\hline Jordan & 4.52 & 4.96 & 24.64 & -13.45 & 18.66 \\
\hline Bahrain & 4.42 & 4.51 & 20.38 & -7.56 & 12.87 \\
\hline Turkey & 4.33 & $4.41\left[\Gamma \mid \Gamma_{0}\right.$ & 19.47 & -5.70 & 9.49 \\
\hline Morocco & 3.81 & 4.68 & 21.91 & -6.58 & 12.22 \\
\hline Slovakia & 3.76 & 8.86 & 78.50 & -14.57 & 42.12 \\
\hline Poland & 3.52 & 2.63 & 6.92 & -7.00 & 7.09 \\
\hline Colombia & 3.47 & 2.26 & 5.10 & -4.20 & 6.90 \\
\hline Kuwait & 3.44 & 10.77 & 116.04 & -19.03 & 33.99 \\
\hline United Arab Emirates & 3.41 & 6.96 & 48.43 & -18.78 & 17.53 \\
\hline Philippines & 3.16 & 3.52 & 12.37 & -7.32 & 7.63 \\
\hline Peru & 3.10 & 6.15 & 37.83 & -11.80 & 12.82 \\
\hline Argentina & 2.62 & 6.51 & 42.40 & -10.89 & 12.67 \\
\hline Brazil & 2.60 & 3.32 & 11.05 & -4.39 & 7.99 \\
\hline Mexico & 2.42 & 3.64 & 13.28 & -6.22 & 8.77 \\
\hline South Africa & 2.30 & 2.42 & 5.85 & -2.14 & 5.60 \\
\hline
\end{tabular}




\begin{tabular}{llllll} 
Czech Republic & 2.08 & 3.53 & 12.46 & -11.61 & 6.81 \\
Estonia & 1.92 & 7.37 & 54.35 & -21.17 & 10.80 \\
Bulgaria & 1.87 & 5.30 & 28.05 & -9.12 & 10.94 \\
Lithuania & 1.63 & 7.69 & 59.15 & -21.26 & 10.25 \\
\hline Latvia & 1.59 & 9.26 & 85.82 & -32.12 & 12.23 \\
Hungary & 1.32 & 3.75 & 14.07 & -11.89 & 6.22 \\
Romania & 1.24 & 5.71 & 32.55 & -12.90 & 9.43 \\
Russia & 1.12 & 6.32 & 39.90 & -14.53 & 10.00 \\
\hline
\end{tabular}

Table 2: Descriptive Statistics of annual mean GDP in billions from 1981-2010

\begin{tabular}{|c|c|c|c|c|c|c|c|c|c|c|}
\hline \multirow[b]{2}{*}{ China } & \multicolumn{2}{|c|}{ Mean } & \multicolumn{2}{|c|}{$\begin{array}{l}\text { Std } \\
\text { Deviation }\end{array}$} & \multicolumn{2}{|c|}{ Variance } & \multicolumn{2}{|c|}{ Minimum } & \multicolumn{2}{|c|}{ Maximum } \\
\hline & $\$ 1,2$ & 62.17 & $\$$ & $1,036.35$ & $\$$ & $1,074,014.61$ & $\$$ & 216.31 & $\$$ & $3,834.55$ \\
\hline Russia & $\$$ & 719.16 & $\$$ & 138.46 & $\$$ & $19,170.19$ & $\$$ & 484.77 & $\$$ & 943.87 \\
\hline Brazil & $\$$ & 712.19 & $\$$ & 170.77 & $\$$ & $29,162.93$ & $\$$ & 476.71 & $\$$ & $1,092.51$ \\
\hline Mexico & $\$$ & 663.47 & $\$$ & 158.23 & $\$$ & $25,035.69$ & $\$$ & 460.50 & $\$$ & 935.60 \\
\hline India & $\$$ & 527.64 & $\$$ & 292.24 & $\$$ & $85,401.51$ & $\$$ & 201.39 & $\$$ & $1,241.58$ \\
\hline Turkey & $\$$ & 335.60 & $\$$ & 121.62 & $\$$ & $14,791.33$ & $\$$ & 162.49 & $\$$ & 564.02 \\
\hline Poland & $\$$ & 227.07 & $\$$ & 74.75 & $\$$ & $5,587.47$ & $\$$ & 136.60 & $\$$ & 382.46 \\
\hline Indonesia & $\$$ & 202.78 & $\$$ & 85.72 & $\$$ & $7,347.64$ & $\$$ & 80.88 & $\$$ & 377.28 \\
\hline South Africa & $\$$ & 196.83 & $\$$ & 44.21 & $\$$ & $1,954.95$ & $\$$ & 147.13 & $\$$ & 288.44 \\
\hline Argentina & $\$$ & 152.27 & $\$$ & 40.19 & $\$$ & $1,615.02$ & $\$$ & 106.38 & $\$$ & 253.62 \\
\hline Thailand & $\$$ & 118.52 & $\$$ & 52.84 & $\$$ & $2,792.52$ & $\$$ & 41.77 & $\$$ & 210.08 \\
\hline Colombia & $\$$ & 113.13 & $\$$ & 34.52 & $\$$ & $1,191.77$ & $\$$ & 66.38 & $\$$ & 183.22 \\
\hline Czech Republic & $\$$ & 103.95 & $\$$ & 19.02 & $\$$ & 361.64 & $\$$ & 77.92 & $\$$ & 144.67 \\
\hline Romania & $\$$ & 90.30 & $\$$ & 14.21 & $\$$ & 202.05 & $\$$ & 70.71 & $\$$ & 123.89 \\
\hline United Arab Emirates & $\$$ & 88.64 & $\$$ & 37.33 & $\$$ & $1,393.41$ & $\$$ & 45.58 & $\$$ & 165.23 \\
\hline Malaysia & $\$$ & 88.02 & $\$$ & 44.72 & $\$$ & $1,999.45$ & $\$$ & 30.82 & $\$$ & 171.47 \\
\hline Hungary & $\$$ & 87.04 & $\$$ & 14.20 & $\$$ & 201.73 & $\$$ & 69.71 & $\$$ & 112.81 \\
\hline Chile & $\$$ & 78.25 & $\$$ & 35.20 & $\$$ & $1,239.30$ & $\$$ & 32.32 & $\$$ & 138.73 \\
\hline Pakistan & $\$$ & 78.08 & $\$$ & 31.21 & $\$$ & 973.88 & $\$$ & 32.79 & $\$$ & 139.62 \\
\hline Philippines & $\$$ & 76.78 & $\$$ & 23.91 & $\$$ & 571.82 & $\$$ & 49.28 & $\$$ & 131.14 \\
\hline Egypt & $\$$ & 68.61 & $\$$ & 28.01 & $\$$ & 784.31 & $\$$ & 30.80 & $\$$ & 131.24 \\
\hline Peru & $\$$ & 62.90 & $\$$ & 19.00 & $\$$ & 361.14 & $\$$ & 43.75 & $\$$ & 112.14 \\
\hline Slovakia & $\$$ & 52.88 & $\$$ & 15.22 & $\$$ & 231.73 & $\$$ & 29.45 & $\$$ & 85.84 \\
\hline Kuwait & $\$$ & 52.85 & $\$$ & 21.14 & $\$$ & 447.08 & $\$$ & 28.60 & $\$$ & 95.24 \\
\hline Morocco & $\$$ & 44.33 & $\$$ & 14.65 & $\$$ & 214.53 & $\$$ & 24.63 & $\$$ & 75.41 \\
\hline Bulgaria & $\$$ & 24.63 & $\$$ & 4.46 & $\$$ & 19.86 & $\$$ & 19.58 & $\$$ & 34.80 \\
\hline Oman & $\$$ & 22.41 & $\$$ & 9.52 & $\$$ & 90.72 & $\$$ & 7.01 & $\$$ & 42.38 \\
\hline Lithuania & $\$$ & 21.39 & $\$$ & 4.66 & $\$$ & 21.72 & $\$$ & 13.91 & $\$$ & 31.67 \\
\hline Sri Lanka & $\$$ & 17.08 & $\$$ & 7.24 & $\$$ & 52.35 & $\$$ & 8.01 & $\$$ & 33.25 \\
\hline Latvia & $\$$ & 12.77 & $\$$ & 3.16 & $\$$ & 10.00 & $\$$ & 8.12 & $\$$ & 19.80 \\
\hline Estonia & $\$$ & 10.26 & $\$$ & 2.66 & $\$$ & 7.07 & $\$$ & 6.68 & $\$$ & 16.42 \\
\hline Bahrain & $\$$ & 9.00 & $\$$ & 4.12 & $\$$ & 16.98 & $\$$ & 4.38 & $\$$ & 17.82 \\
\hline Jordon & $\$$ & 8.78 & $\$$ & 3.61 & $\$$ & 13.01 & $\$$ & 4.60 & $\$$ & 16.74 \\
\hline
\end{tabular}


Mauritius

$\$ \quad 4.35 \$$

$1.86 \$$

$3.44 \$$

$1.79 \$$

7.82

Table 3: Debt incurred by countries through IMF lending

\begin{tabular}{|c|c|c|}
\hline Country & Total Amt drawn in SDR's (millions) & IMF credit status \\
\hline Argentina & $23,478,810.00$ & 0 \\
\hline Brazil & $62,128.72$ & 0 \\
\hline Turkey & $36,099.00$ & 1 \\
\hline Indonesia & $11,104.82$ & 0 \\
\hline Romania & $10,100.00$ & 1 \\
\hline Hungary & $7,693.70$ & 1 \\
\hline Russia & $6,926.16$ & 0 \\
\hline Pakistan & $6,262.46$ & 1 \\
\hline India & $6,107.93$ & 0 \\
\hline Thailand & $2,760.00$ & 0 \\
\hline Mexico & $1,939.50$ & 0 \\
\hline Philippines & 30 & 0 \\
\hline Chile & $1,370.25$ & 0 \\
\hline Latvia & 982.24 & 1 \\
\hline Bulgaria & 867.62 & 0 \\
\hline China & 597.73 & 0 \\
\hline Jordan & 341.06 & 1 \\
\hline Poland & 283.30 & 0 \\
\hline Morocco & 276.40 & 0 \\
\hline Sri Lanka & 205.89 & 1 \\
\hline Egypt & 147.20 & 0 \\
\hline Lithuania & 134.55 & 8 \\
\hline Mauritius & 98.50 & 0 \\
\hline Czech Republic & 70.00 & 0 \\
\hline Slovakia & 32.15 & 0 \\
\hline Bahrain & 0.00 & -1 \\
\hline Colombia & 0.00 & -1 \\
\hline Estonia & 0.00 & -1 \\
\hline Kuwait & 0.00 & -1 \\
\hline Malaysia & 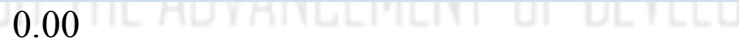 & $-1+\frac{1}{1}$ \\
\hline Oman & 0.00 & -1 \\
\hline Peru & 0.00 & -1 \\
\hline Qatar & 0.00 & -1 \\
\hline South Africa & 0.00 & -1 \\
\hline United Arab Emirates & 0.00 & -1 \\
\hline
\end{tabular}

Note: Special Drawing Rights (SDRs) is an asset of the IMF known as international reserves designed to supplement the reserves of its member countries.

The next step in our procedure was to complete several regressions. The purpose of the regressions is to analyze the relationships between average annual GDP, GDP growth variance, IMF loan 
position, and total debt incurred courtesy the IMF. Our goal in this process is to determine whether the independent variables are significant, correlated, or causal of other variables.

In Regression 1, the dependent variable is the total amount withdrawn in millions by all the debtor countries in our sample. The exogenous variables are the GDP growth rates of these countries from the period 2000-2010.

Table 4: OLS Regression and ANOVA table with amount withdrawn in millions as the dependent variable and countries' annual GDP growth rates as independent variables.

\begin{tabular}{|c|c|c|c|c|c|}
\hline \multicolumn{2}{|c|}{ Regression Statistics } & & & & \\
\hline Multiple R & 0.934034 & & & & \\
\hline R Square & 0.872419 & & & & \\
\hline Adjusted R Square & 0.808629 & & & & \\
\hline Standard Error & 1761117 & & & & \\
\hline Observations & 34 & & & & \\
\hline \multicolumn{6}{|l|}{ ANOVA } \\
\hline & df & SS & MS & $\mathrm{F}$ & Significance $\mathrm{F}$ \\
\hline Regression & 11 & $4.67 \mathrm{E}+14$ & $4.24 \mathrm{E}+13$ & 13.67633 & 2.07E-07 \\
\hline Residual & 22 & $6.82 \mathrm{E}+13$ & $3.1 \mathrm{E}+12$ & & \\
\hline \multirow[t]{2}{*}{ Total } & 33 & $5.35 \mathrm{E}+14$ & & & \\
\hline & Coefficients & \multicolumn{2}{|c|}{ Standard Error } & t Stat & P-value \\
\hline Intercept & -2393561 & \multicolumn{2}{|c|}{1696382} & -1.41098 & 0.172236 \\
\hline Growth_Rate2000 & -36058.6 & \multicolumn{2}{|c|}{172589.4} & -0.20893 & 0.836428 \\
\hline Growth_Rate2001 & 190485.2 & \multicolumn{2}{|c|}{145744.9} & 1.306977 & 0.204718 \\
\hline Growth_Rate2002*** & -1215508 & \multicolumn{2}{|c|}{137118.8} & -8.86464 & $1.03 \mathrm{E}-08$ \\
\hline Growth_Rate2003 & -40349.1 & \multicolumn{2}{|c|}{165271.6} & -0.24414 & 0.809386 \\
\hline Growth_Rate2004 & 241929.9 & \multicolumn{2}{|c|}{295277.2} & 0.819332 & 0.421385 \\
\hline Growth_Rate2005 & 372910 & \multicolumn{2}{|c|}{285208} & 1.307502 & 0.204542 \\
\hline Growth_Rate2006 & 31442.57 & \multicolumn{2}{|c|}{241697.3} & 0.130091 & 0.897677 \\
\hline Growth_Rate2007 & 78188.27 & \multicolumn{2}{|c|}{239722.5} & 0.326162 & 0.747384 \\
\hline Growth_Rate2008 & 156431.3 & \multicolumn{2}{|c|}{165187.4} & 0.946993 & 0.353929 \\
\hline Growth_Rate2009** & -220924 & \multicolumn{2}{|c|}{82425.89} & -2.68027 & 0.01367 \\
\hline Growth_Rate02010** & 379112.5 & \multicolumn{2}{|c|}{170908.4} & 2.21822 & 0.037171 \\
\hline
\end{tabular}

$* * *=$ significant at $1 \%$ level; $* *=$ significant at $5 \%$ level; $*=$ significant at $10 \%$ level 
Regression equation:

Ttl_Amt_Wthdrawn $=-2.39 * 10^{6}-3.61 * 10^{4} \mathrm{Xt}_{\mathrm{t}}+1.90 * 10^{5} \mathrm{X}_{\mathrm{t}+1}-1.21 * 10^{6} \mathrm{X}_{\mathrm{t}+2}-4.03 * 10^{4}$

$\mathrm{X}_{\mathrm{t}+3}+2.42 * 10^{5} \mathrm{X}_{\mathrm{t}+4}+3.73 * 10^{5} \mathrm{X}_{\mathrm{t}+5}+3.14 * 10^{4} \mathrm{X}_{\mathrm{t}+6}+7.82 * 104 \mathrm{X}_{\mathrm{t}+7}+1.56^{*} 10^{5} \mathrm{X}_{\mathrm{t}+8}-2.21 * 105$

$\mathrm{X}_{\mathrm{t}+9}+3.79 * 105 \mathrm{X}_{\mathrm{t}+10}$

Equation 1 is such that $\mathrm{Xt}=$ annual growth rate in year 2000. The R-square of our regression is 0.87 ; however, this is mostly caused by the correlation between our $\mathrm{X}$ variables. Nonetheless, the growth rates of 2009 which are significant at the 5 percent level are negative. The year 2009 is the documented climax of the 2007-2009 financial crisis. A negative coefficient indicates that as growth rates rise in that year, the amount borrowed by the country should decrease. This illustrates that there exists a negative relationship between IMF debt and growth rates as hypothesized. Additionally, in 2010, the coefficient of the growth rates predictor is positive, which indicates that at the end of the crisis, borrowing may have been positively correlated with growth rates.

In regression 2, the data selected holds the IMF status: $1=$ currently indebted to the Fund and $-1=$ never engaged in borrowing from the IMF. The dependent variable is the log of average annual GDP from 1981-2010. The independent variables are IMF credit status, ratio of amount withdrawn to average annual GDP, and total amount withdrawn.

Table 5: OLS Regression with countries of IMF status 1, -1

(Currently owe IMF and never borrowed funds from IMF) dependent variable is log GDP

\begin{tabular}{|c|c|c|c|c|}
\hline \multicolumn{2}{|l|}{ Regression Statistics } & & & \multirow{8}{*}{$\begin{array}{cl}\text { F } & \text { Significance } \\
1.906103811 & 0.182466718\end{array}$} \\
\hline Multiple R & 0.568097315 & & & \\
\hline R Square & 0.322734559 & & & \\
\hline Adjusted R Square & 0.153418199 & & & \\
\hline Standard Error & 0.460514658 & & & \\
\hline Observations & 16 & & & \\
\hline ANOVA & $\mathrm{df}$ & SS & MS & \\
\hline Regression & 3 & 1.212703751 & 0.404234584 & \\
\hline Residual & 12 & 2.544885004 & 0.21207375 & \\
\hline \multirow[t]{2}{*}{ Total } & 15 & 3.757588755 & & \\
\hline & Coefficients & Standard Error & t Stat & P-value \\
\hline Intercept & 2.069159133 & 0.162281829 & 12.75040553 & $2.45324 \mathrm{E}-08$ \\
\hline IMF credit status & -0.012654546 & 0.162281829 & -0.077978821 & 0.939130074 \\
\hline $\begin{array}{l}\text { Ratio of } \\
\text { Withdrawn:GDP }\end{array}$ & -0.003476915 & 0.00380212 & -0.91446744 & 0.378479895 \\
\hline Total withdrawn & $-2.02863 \mathrm{E}-05$ & $1.49283 \mathrm{E}-05$ & -1.358919272 & 0.199165817 \\
\hline
\end{tabular}

Regression equation:

Lg Mean GDP= 2.07 -0.01 IMF credit status - $\mathbf{0 . 0 0 3}$ Amt owed: GDP - .00002 Total withdrawn (2) 
From equation (2) we can see that the ratio of amount owed to IMF to GDP and the total amount withdrawn has a negative impact on the mean GDP of the country. However, these variables are not significant at a 5\% level of significance, so we do not consider them.

Table 6: OLS Regression with countries of IMF status 1, 0

(Currently owe IMF and fully repaid debt to IMF) dependent variable is log GDP

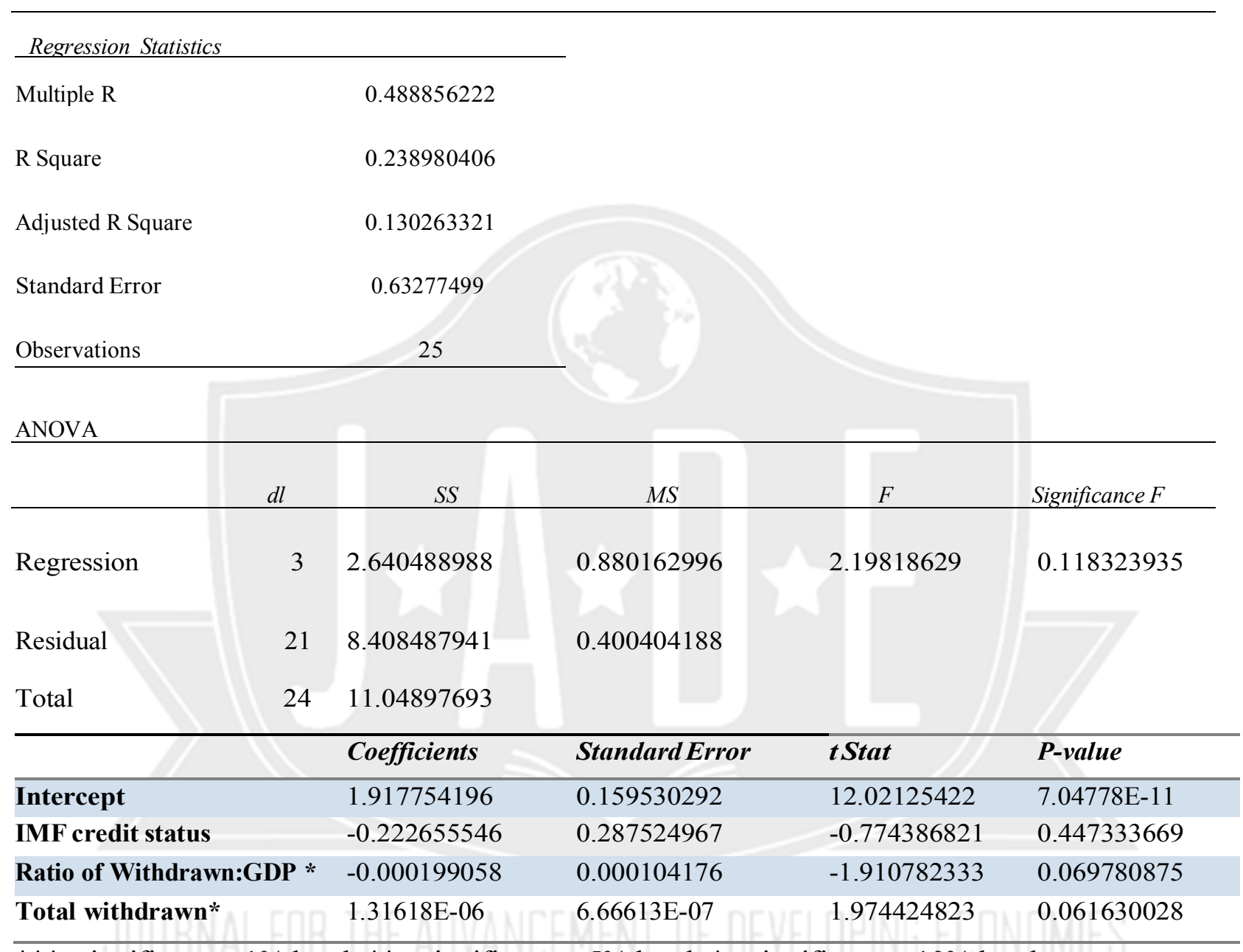

$* * *=$ significant at $1 \%$ level; $* *=$ significant at $5 \%$ level; $*=$ significant at $10 \%$ level

Regression equation:

Lg Mean GDP= 1.92 - 0.22 IMF credit status - 0.000 Amt owed: GDP - .000001 Total withdrawn (3)

Equation (3) exhibits similar characteristics as equation (2); however, in equation (3) the ratio of amount withdrawn to GDP and total amount withdrawn are significant at a 10 percent level. Since the two groups in the discussion are countries that both owed the IMF but one group fully repaid the debt while one is still indebted to the Fund, the total amount withdrawn is indicative of the fact that if we consider independently countries that repaid their debt versus countries that were unable 
to repay their debt then the total withdrawn and the ratio of the amount withdrawn to GDP affects the country's average annual GDP growth rate.

Regression 4 considers countries that never owed the IMF and those that no longer owe the Fund.

Table 7: OLS Regression with countries of IMF status $-1,0$

(Never engaged in IMF borrowing and currently paid their debt) dependent variable is log GDP

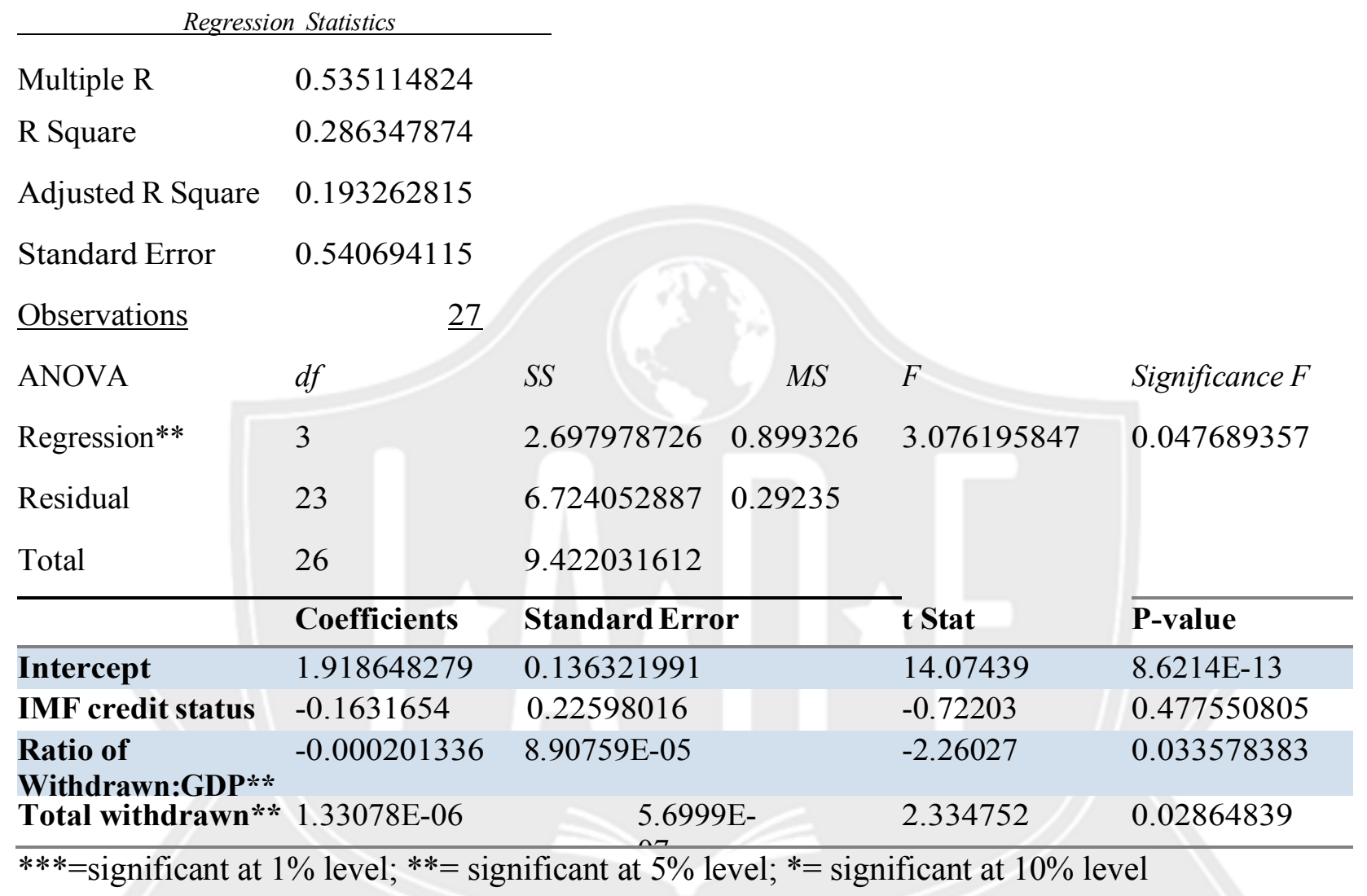

Regression equation:

Lg Mean GDP= 1.92 - 0.16 IMF credit status - 0.000 Amt owed: GDP - .000001 Total withdraw (4)

Equation (4) illustrates that when we consider countries that currently do not owe the IMF and countries that never owed the IMF, there is significance in the regression at a 5 percent level. In addition, the total amount withdrawn, and the amount withdrawn to GDP ratio are also significant at a 5 percent level. Therefore, we can assert that there is a significant difference in the growth rates of countries who took an IMF loan versus those who never took on their debt regardless of their ability to repay the debt.

The next step of our analysis considers the causal relationship between the variables. When we conduct Granger Causality tests, Table 8 yields our results. 
Table 8: Pairwise Granger Causality Tests among Variables

\section{Pairwise Granger Causality Tests}

\begin{tabular}{lccc}
\hline Lags: 2 & Obs & F-Statistic & Probability \\
\hline GROWTH_RATES does not Granger Cause LOG_AVG_GDP** & 32 & 3.50933 & 0.04418 \\
\hline LOG_AVG_GDP does not Granger Cause GROWTH_RATES & & 1.07407 & 0.35577 \\
\hline GROWTH_RATES does not Granger Cause IMF_CREDIT_STATUS** & 32 & 5.10114 & 0.0132 \\
\hline IMF_CREDIT_STATUS does not Granger Cause GROWTH_RATES & & 0.0156 & 0.98453 \\
\hline AVG_GROWTH_RATE does not Granger Cause IMF_CREDIT_STATUS & 32 & 2.14053 & 0.13712 \\
\hline IMF_CREDIT_STATUS does not Granger Cause & & 3.15063 & 0.05891 \\
\hline AVG GROWTH RATE* & & 1.89427 & 0.16989 \\
\hline AVG_GROWTH_RATE does not Granger Cause GROWTH_RATES & 32 & 1.19586 & 0.31796 \\
\hline GROWTH_RATES does not Granger Cause AVG_GROWTH_RATE & & \\
\hline
\end{tabular}

$* * *=$ significant at $1 \%$ level; $* *=$ significant at $5 \%$ level; $*=$ significant at $10 \%$ level

The results of our Granger Causality tests in Table 8 indicate that at a 10 percent level of significance, IMF credit status Granger Causality tests cause average annual growth rates. This supports our hypothesis that a country's debt relationship with the Fund does affect their GDP growth rates.

\section{$4 \quad$ RESULTS}

Essentially, we can conclude that there exists a causal relationship between IMF credit status and average growth rates. This relationship is identified by Granger Causality tests. In addition, when we consider two groups of the three, (never undertook debt, fully repaid debt and currently indebted) in one regression, we find that total amount withdrawn, and the ratio of amount withdrawn, and GDP are significant explanatory variables in determining average annual growth rates. In both equations (3) and (4), the ratio of amount withdrawn to GDP is negative and significant at the 10 percent and 5 percent level of significance. This is indicative that this amount withdrawn has a negative impact on the log of average GDP. The implication of the result is that borrowing from the IMF, which was designed to boost the borrower's economy, is actually having a negative impact on the country's growth rate.

\section{$5 \quad$ CONCLUSIONS AND POLICY IMPLICATIONS}

Our results indicate that the debt relationship between emerging markets and the IMF plays an integral role in determining the growth rates of these counties' GDP. Ultimately, these results implicate the need for several IMF policy adjustments.

Firstly, many of the decisions made by the IMF are advised informally by countries represented by the G-7, G-20 and G-24. The majority of these countries are not emerging markets and, 
consequently the decisions made by the IMF are not always in the best interest of emerging markets' economies. The Board of Governors, the head of the decision-making body of the IMF, needs to be comprised of more emerging markets or at least better represented by them.

In addition, the IMF needs to be more diligent in following up on its debtors after the loan has been dispersed. Initially, there are certain requirements that the country must meet in order to qualify to participate in the SDR program. However, if the program is designed to inject funds into an economy to assist it to function better and if the countries are experiencing a decline in GDP after borrowing, then they are not using the funds as initially indicated.

According to the IMF, its conditions for lending often stem from a country's state of being either in or near an economic crisis. Evidently, the IMF can stand to be more proactive in detecting countries that are beginning on a steady decline to provide funds with a more preventative motive than crisis assistance.

Ultimately, we can conclude that the answer to our research question is not to prevent emerging markets from borrowing from the IMF but to encourage the IMF to do more due diligence on its member countries to prevent them from experiencing a crisis as well as following up on their progress after the finances are dispersed. Additionally, it is critical for emerging markets around the globe to have a greater presence on the Fund's Board of Governance so that their interests can be equally attended to.

\section{REFERENCES}

Bartelsman, E., \& Beaulieu, J. (2004). A Consistent Accounting of U.S. Productivity Growth. Finance and Economics Discussion Series from Board of Governors of the Federal Reserve System (U.S.). No 2004-55. (Working Paper).

Bird, G. (1996). Borrowing from the IMF: The policy implications of Recent Empirical Research. World Development, 24(11), 1753-1760.

Chang, R., \& Velasco, A. (2001). A model of Financial Crises in Emerging Markets. Quarterly Journal of Economics, 116 (2), 489-517.

Dombusch, R., Park, Y.C. \& Claessens, S. (2000). Contagion: Understanding How It Spreads.

World Bank Research Observer 15(2), 177-197.

Edwards, S., \& Santaell, J. A., (1993). Devaluation Controversies in the Developing Countries: Lessons from the Bretton Woods Era. In: Bordo, M.D., Eichengreen, B. (Eds.), A Retrospective on the Bretton Woods System, (pp. 405-460). University of Chicago Press, Chicago.

Feldstein, M. (1998). Refocusing the IMF. Foreign Affairs, 77(2), 20-33.

Frankel, J. A., \& Roseb, A.K. (1996). Currency crashes in emerging markets: An empirical treatment Journal of International Economics, 41, 351-366.

International Monetary Fund, Retrieved on January 2012. http://www.imf.org/external/index.htm. Joyce, J.P. (1992). The economic characteristics of IMF program countries, Economics Letters, $38(2), 237-242$.

Kenen, P.B. (1994). Exchange rates and the monetary system: selected essays of Peter B. Kenen, 
Edward Elger Publishing.

Knight, M. \& Santaella, J.A. (1997), Economic determinants of IMF financial arrangements.

Journal of Development Economics. 54(2), 405-436.

Li, C. (2012). What are emerging markets? The University of Iowa Center for International Finance and Development. [web log comment] Retrieved on January 8, 2012 from http://blogs.law.uiowa.edu/ebook/faqs/what-are-emerging-markets

Masson, P. R., (1998). Contagion: monsoonal effects, spillovers and jumps between multiple equilibria. IMF Working Paper No 98/142.

Masson, P. (1999). Multiple Equilibria, contagion and the emerging market crises, IMF Working Paper No 99/164.

Mody, A. (2004, September). What is an emerging market? IMF Working Paper WP/04/177.

Pendery, D. (2009). Three top economists agree 2009 worst financial crisis since great depression; risks increase if right steps are not taken. Business Wire News database. Retrieved from http://www.businesswire.com/news/home/20090213005161/en/Top Economists-Agree2009-Worst-Financial-Crisis.

The World Bank Group, (2012). World Development Indicators. Retrieved from http://data.worldbank.org/data-catalog/world-development-indicators on (January 2012). 